\title{
Regional survey and identification of Bipolaris spp. associated with rice seeds in Rio Grande do Sul State, Brazil
}

\author{
Levantamento regional e identificação de Bipolaris spp. associadas às sementes de arroz \\ no Estado do Rio Grande do Sul, Brasil
}

\author{
Cândida Renata Jacobsen de Farias ${ }^{\mathrm{I}}$ Ana Paula Schneid Afonso ${ }^{\mathrm{II}}$ \\ Carlos Roberto Pierobom ${ }^{\mathrm{I}}$ Emerson Medeiros Del Ponte ${ }^{\mathrm{III}}$
}

\section{- NOTE -}

\begin{abstract}
In the harvest year of 2004, a random sample of seed lots $(n=165)$ from six rice-growing regions of Rio Grande do Sul (RS) State, Brazil, were examined under seed health blotter test. Fungi growth resembling Bipolaris or Drechslera spp. was isolated and identified at the species level. Observations on the anamorphic structures (conidiophores and conidia) allowed separation of isolates into three groups. Pseudothecia, asci and ascospores from sexual crosses between isolates from a same anamorphic group but originated from different regions showed the typical characteristics of three recognized species (anamorph/ teleomorph): Bipolaris cynodontis (Cochliobolus cynodontis); $\boldsymbol{B}$. curvispora (C. melinidis) and B. oryzae (C. miyabeanus). All species were widely distributed across the rice-growing regions. Overall, the most prevalent species were $\boldsymbol{B}$. oryzae $(44.6 \%)$ and $\boldsymbol{B}$. curvispora $(42,9 \%)$ followed by B. cynodontis $(24,1 \%)$. This is the first report of $\boldsymbol{B}$. cynodontis associated with rice seeds in Brazil and the preliminary identification of $\boldsymbol{B}$. curvispora in rice by the observation of the teleomorph phase was confirmed. The regional occurrence of a complex of pathogenic Bipolaris species related to brown spot epidemics in other countries, may have epidemiological consequences in the region which deserve further investigation.
\end{abstract}

Key words: Oryza sativa L., seed pathology, Helminthosporium RESUMO

Uma amostra aleatória $(n=165)$ de lotes de sementes de seis regiões produtoras de arroz no Estado do Rio Grande do Sul (RS), Brasil, ano de colheita 2004, foi examinada em teste blotter de sanidade de sementes. Fungos semelhantes a espécies de Bipolaris e Drechslera foram isolados para identificação das espécies. A observação de estruturas da fase anamórfica (conidióforos e conídios) permitiu separar os isolados em três grupos. Cruzamentos sexuais induzidos em isolados do mesmo grupo, mas originados de diferentes regióes, resultaram em pseudotécio, ascos e ascósporos, permitindo a identificação de três espécies (anamorfo/teleomorfo): Bipolaris cynodontis (Cochliobolus cynodontis); B. curvispora (C. melinidis) e B. oryzae (C. miyabeanus). Todas as espécies estavam distribuídas nas seis regiões produtoras no Rio Grande do Sul. Em geral, a espécie mais prevalente nas amostras foi B. oryzae $(44,6 \%)$ e B. curvispora (42,9\%) seguido de B. cynodontis $(24,1 \%)$. Este é o primeiro relato de $\boldsymbol{B}$. cynodontis associada a sementes de arroz no Brasil, e confirma-se a ocorrência de B. curvispora pela observação da fase teleomórfica. A ocorrência de um complexo de espécies patogênicas de Bipolaris, relacionadas com a mancha parda em outros países, pode ter consequências epidemiológicas na região, o que merece futura atenção.

Palavras-chave: Oryza sativa, patologia de sementes, Helminthosporium

Brown spot, caused by Bipolaris oryzae (Breda de Haan) Shoemaker, is a well-known fungal disease in Brazil (RIBEIRO, 1979) that has increased in concern in the last years, especially due to its frequent occurrence and damage in rice kernels (FARIAS et al., 2005; MALAVOLTAet al., 2007). The resurge may be due to a combination of factors related to changes in rice varieties, management practices that favor disease development and seed infection (OU, 1985). A typical seed-

\footnotetext{
'Departamento de Fitossanidade, Faculdade de Agronomia Eliseu Maciel, Universidade Federal de Pelotas (UFPel), 96010-610, Pelotas, RS, Brasil.

"Embrapa Clima Temperado, Pelotas, RS, Brasil.

"'Departamento de Fitossanidade, Faculdade de Agronomia, Universidade Federal do Rio Grande do Sul (UFRGS), Porto Alegre, RS, Brasil. E-mail: emerson.delponte@ufrgs.br. Autor para correspondência.
} 
borne fungus, $\boldsymbol{B}$. oryzae reduces the crop stand due to seedling blight and can survive internally in the seed for many years (OU, 1985). Other Bipolaris spp. were found associated with rice seeds in samples from all over the world such as B. bicolor (Mitra) Shoem and B. victoriae (F. Meehan \& H.C. Murphy) Shoemaker (SIVANESAN, 1987; MATHUR \& NEERGAARD, 1973). For instance, in a recent study conducted in Iran, $\boldsymbol{B}$. victoriae, B. oryzae, B. indica Rai, Wadhwani \& Tewari and $\boldsymbol{B}$. bicolor were identified associated to brown spot lesions in rice leaves, being $\boldsymbol{B}$. victoriae the most prevalent species $(85 \%)$ (MOTLAGH \& KAVIANI, 2008). Recent information from southern Brazilian ricegrowing regions revealed $B$. oryzae in much higher prevalence and incidence levels (FARIAS et al., 2005) compared to previous decades (1993 to 1998) (FRANCO et al., 2001). Given the previous observation of $\boldsymbol{B}$. curvispora associated to rice seeds produced in the region, identified based on the anamorphic structures (FARIAS \& PIEROBOM, 2004), the hypothesis of this research was that other species could be identified by sampling a higher number of seed lots from all production regions, basing the identification on the teleomorphs to draw conclusive information. Therefore, the objectives of this study were to 1) build a collection of isolates resembling Bipolaris/Drechslera spp. obtained from seed lots from six production regions of Rio Grande do Sul state, Brazil; 2) identify isolates at the species levels; and 3) determine the prevalence of the fungal species across the regions.

Rice seed lots $(n=165)$ were obtained from certified seed-production fields harvested in 2004 across six rice-growing regions in RS state. A 400-seed random sample from each lot was examined using a standard blotter test (NEERGARD, 1979). Seven days after incubation, a random sample of fungal isolates resembling Bipolaris whenever found during inspection were transferred to PDA (Potato-DextroseAgar) media. At least one isolate per seed lot was obtained. Shape and germination pattern of conidia form monosporic culture after 7-day of growth was observed under a stereoscopic microscope (40x). Microscopic slides were prepared and 100 conidia were assessed for number of septum, width and length. Conidia color and shape, morphology of the conidiophores and characteristics of the fungi colony on infected kernels were also evaluated (SIVANESAN, 1987). Conidial suspensions of isolates for all possible pair-wise combinations of anamorphic groups and region of origin were mixed and grown in artificial media to induce pseudothecia formation by sexual cross. Three substrates were tested: I) a bottom single layer of blotter paper, an intermediate layer of filter paper and sterilized Typha sp. leaves on the top layer; II) a bottom single layer of blotter paper and an upper layer of sterilized rice seeds; III) a bottom layer of Sach's media, an intermediate layer of filter paper and an upper layer of sterilized Typha sp. leaves. Plates were incubated under a controlled environment at $25^{\circ} \mathrm{C}$ and 12 hours of light and 12 hours of dark during a period of 45 days or until pseudothecia formation (SIVANESAN, 1987). Pseudothecia were transferred onto slides and gently pressed for the release of the ascus and the ascospores. Sexual structures were measured and compared to the literature (MATHUR \& NEERGAARD, 1973; SIVANESAN, 1987). The occurrence of the identified species in each seed lot was noted after description of the typical morphology of the anamorphic phase growing on seeds in the blotter test. Prevalence maps were made do depict the proportion of seed lots from a single region where the species were found.

The results showed key characteristics of Bipolaris genus in all isolates studied: fusoid and curved conidia that germinate from either apical or basal cells, or from both, and never from the other cells of the conidia, as expected for Drechslera species (ALCORN, 1988). Three anamorphic groups were formed based on conidia shape, size and other characteristics, matched descriptions for the recognized Bipolaris species: B curvispora, B. cynodontis and $\boldsymbol{B}$. oryzae (Figure 1) (SIVANESAN, 1987). Crossings (sexual crosses) between isolates from a same anamorphic group successfully induced sexual reproduction in at least one of the three media used. Although B. oryzae and $\boldsymbol{B}$. curvispora formed pseudothecia, asci and ascospores in the filter paper + Typha sp. substrate, $\boldsymbol{B}$. cynodontis only formed pseudothecia in Sach's agar medium + Typha sp. leaves. Analysis of the sexual structures revealed full match with the descriptions for the respective species in the Cochliobolus genus (Figure 2) (SIVANESAN, 1987). No sexual structures were observed in all media tested during crossings between isolates of different anamorphic groups. Although it was not possible to cross $\boldsymbol{B}$. cynodontis with the ones from other groups because a different substrate was required for sexual reproduction this species showed the most distinct morphology among the groups, allowing a clear separation of this species. The species teleomorph names for the respective anamorphs are: Cochliobolus cynodontis; Cochliobolus melinidis and Cochliobolus miyabeanus.

These data corroborate with early report of the B. curvispora occurrence associated with rice seeds by observing its respective teleomorph phase induced in artificial media. Other known grass hosts 


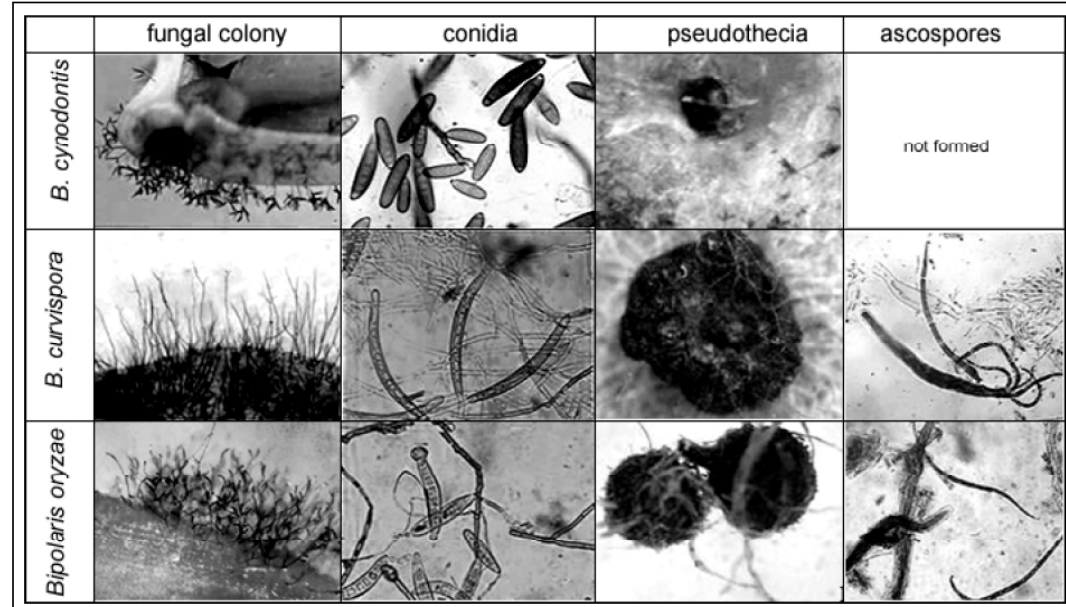

Figure 1 - Characteristics of three Bipolaris spp. isolated from rice seeds and observed under the stereomicroscope (20 to $25 \mathrm{x}$, fungal colony) and microscope (50 a $60 \mathrm{x}$, conidia, pseudothecia and ascospores).

of B. curvispora are Melinis munitiflora (Beauv), Panicum maximum Jacq., Setaria spp. and Triticum aestivum $\mathbf{L}$., in which dark brown necrotic lesions were observed. Other reports of $\boldsymbol{B}$. curvispora distribution were limited to Australia, India, Paraguay and Costa Rica (SIVANESAN, 1987). B. cynodontis was reported in Brazil associated to seeds of Avena strigosa L. (FARIAS et al., 2005), leaves of Heliconia spp. (ASSIS et al., 2002) and Brachiaria brizantha (Hochst. ex A. Rich) Stapf (MACEDO \& BARRETO, 2007). B. cynodontis was recently observed causing brown spot in rice leaves in northwestern Morocco (ZEHHAR et

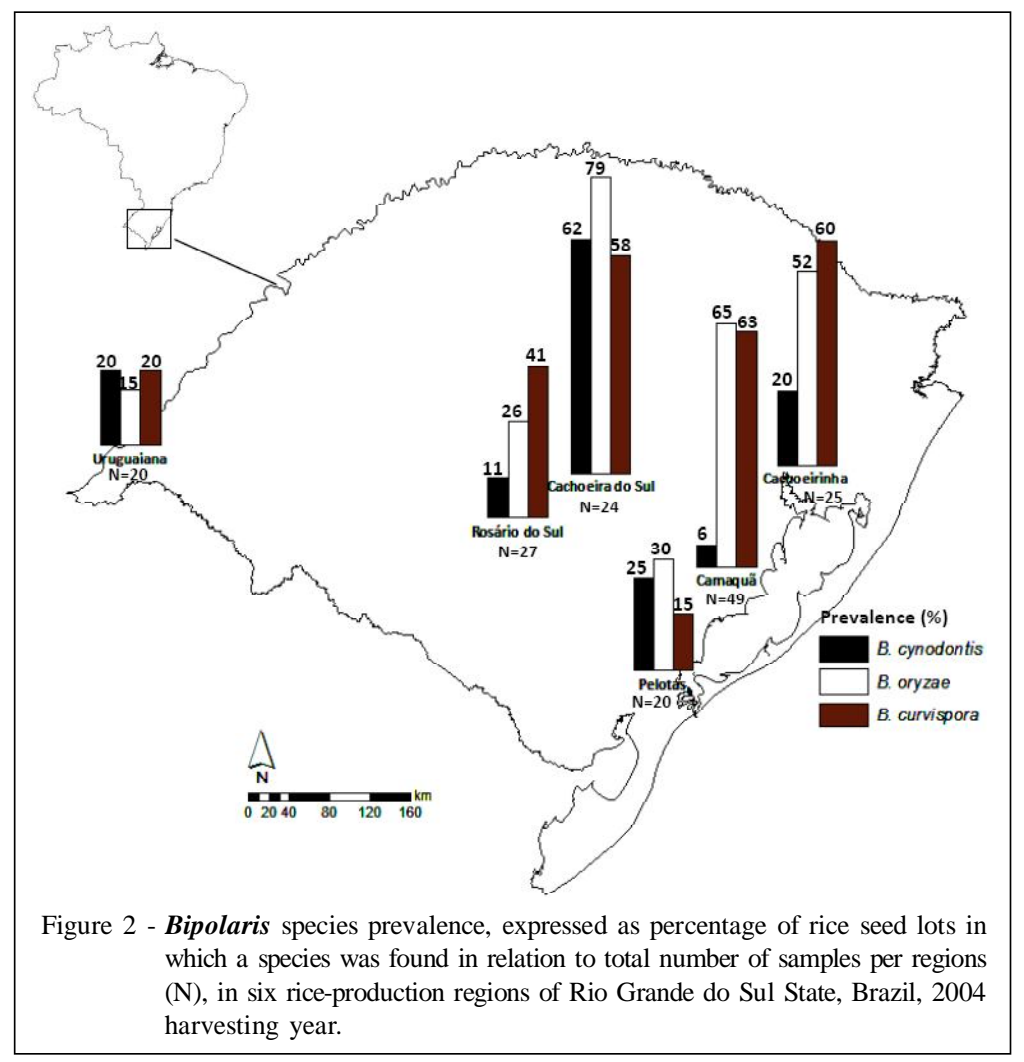

Ciência Rural, v.41, n.3, mar, 2011. 
al., 2008). The three species found in the samples were present in all six rice production regions. Overall prevalence was: B. oryzae $(44,6 \%)$, B. curvispora $(42,9 \%)$ and $\boldsymbol{B}$. cynodontis $(24,1 \%)$. Prevalence levels of species/regions varied from 6\% (B. curvispora in Camaquã) to $79 \%$ (B. oryzae in Cachoeira do Sul). In general, samples from the central and northeastern regions (Cachoeira do Sul, Camaquã and Cachoeira), presented higher prevalence levels of all species, excepting B. curvispora in Camaquã where the lowest prevalence levels were observed (Figure 2). It will be instructive to further investigate the distribution of these species across the years and regions, specially their relative incidence in a single seed lot for a more detailed quantitative assessment of the risk that species other than B. oryzae are contributing to a poor seed health status or causing seedling blight and brown spot.

\section{REFERENCES}

ALCORN, J.L. The taxonomy of "Helminthosporium" species. Annual Review of Phytopathology, v.26, p.37-56, 1988. Disponível em: <https://www.annualreviews.org/doi/abs/10.1146/ annurev.py.26.090188.000345>. Acesso em: 25 mar. 2010.

ASSIS, M.P. et al. Doenças e pragas das helicônias. Recife: Universidade Federal Rural de Pernambuco. 2002. 102p.

FARIAS, C.R.J.; PIEROBOM, C.R. Bipolaris curvispora, um novo patógeno de arroz (Oryza sativa L.). Fitopatologia Brasileira, v.27, p.S146, 2004.

FARIAS, C.R.J. et al. Fungos causadores de helmintosporiose associados às sementes de aveia preta (Avena Strigosa, Schreb). Revista Brasileira de Agrociência, v.11, p.57-61, 2005. Disponível em: <http://www6.ufrgs.br/agronomia/fitossan/ epidemiologia/wp-content/uploads/2009/09/2004Farias_fungos_Agrociencia.pdf $>$. Acesso em: 24 abr. 2010.
FRANCO, D.F. et al. Fungos associados a sementes de arroz irrigado no Rio Grande do Sul. Revista Brasileira de Agrociência, v.7, p.235-236, 2001. Disponível em: <http:// www.ufpel.tche.br/faem/agrociencia/v7n3/artigo16.pdf > . Acesso em: 30 jul. 2010.

MACEDO, D.; BARRETO R.W. First report of leaf blight of Brachiaria brizantha in Brazil caused by Bipolaris cynodontis. Plant Pathology, v.56, p.1041, 2007. Disponível em: <http:/ /www.ndrs.org.uk/article.php?id=014001>. Acesso em: 2 maio, 2010 .

MALAVOLTA, V.M.A. et al. Fungi incidence and damage evaluation on seeds of rice genotypes. Summa Phytopathologica, v.33, p.280-286, 2007. Disponível em: <http://www.scielo.br/ scielo.php?pid=S0100-54052007000300012\&script=sci_abstract $>$. Acesso em: 12 jul. 2010.

MATHUR, P.C.S.B.; NEERGARD, P. Identification of seedborne Drechslera species. Friesia, v.10, p.165-207, 1973.

MOTLAGH, M.R.; KAVIANI, B. Characterization of new Bipolaris spp.: the causal agent of rice brown spot disease in the North of Iran. International Journal of Agricuture and Biology, v.10, p.638-642, 2008. Disponível em: <http:// www.fspublishers.org/ijab/past-issues/IJABVOL_10_NO_6/ 8.pdf>. Acesso em: 4 maio, 2010.

NEERGARD, P. Seed pathology. London: Mac Millan, 1979. $1191 \mathrm{p}$.

OU, S.H. Rice diseases. 2.ed. Slough: CAB International Mycological Institute, 1985. 380p.

SIVANESAN, A. Graminicolous species of Bipolaris, Curvularia, Drechslera, Exserohilum and their teleomorphs. Wallingford, UK: CAB International Mycological Institute, 1987. 261p.

ZEHHAR, G. et al. First report of Bipolaris cynodontis on Oryza sativa in Morocco. Phytopathologia Mediterranea, v.47, p.73-76, 2008. 